\title{
PENGARUH MASSASE TERHADAP PENGURANGAN RASA NYERI PADA IBU INPARTU KALA I DI BPS NURHASANAH KECAMATAN TELUK BETUNG BANDAR LAMPUNG
}

\author{
An Riska ${ }^{1}$, Ana Mariza ${ }^{2}$ \\ ${ }^{1,2}$ Program Studi Kebidanan, Universitas Malahayati \\ Email: mariza.ana22@gmail.com, totti_imut@yahoo.co.id
}

\begin{abstract}
Abstrack: The Effect Massase to the Pain Reduction in The First Stage Inpartu Mother in BPS Nurhasanah, Teluk Betung, Bandar Lampung. Labor pain is generally felt great, and only $2-4 \%$ of women who experienced mild pain during labor. In the management of labor, pain can be reduced by pharmacological and non-pharmacological techniques. One non-pharmacological techniques is Massase. Based on the results prasurvey researchers, pain management that have been done by the mother during this inpartu in BPS were relaxation techniques, distraction by walking, the activity slowly, and the selection of labor positions that are convenient for the mother. This study were to determine the effect Massase to the pain reduction in the first stage inpartu mother in BPS Nurhasanah, 2016. This study were a pre-experimental research design with One Group Pretest-Posttest approach. Sampling was accidental sampling technique. Population was the number of women giving birth during the latter of first month, in May 2016. Total population were 34 mothers. Then, samples were the mother with inpartu first stage in BPS Nurhasanah during the study in June 2016, and total sample were 20 mothers. Data colleted on the observation sheet with Wong Baker pain scale Pain Rating Scale. It was a pain scale based on facial expressions with a score range of 0 to 5. Data analysis used univariate and presented in tabular form distribution level of pain before and after Massase. Then, bivariate analysis used T-test. The results showed that the average labor pain before Massase technique was 3.450 with a standard deviation of 0.944 . Average labor pain after being given Massase technique was 2.400 with a standard deviation of 0.994. There was an influence on the Massase Effect to Pain Reduction on Inpartu Kala Capital I in BPS Nurhasanah, Teluk Betung, Bandar Lampung, 2016 (p-value $0.000<0.05$ ).
\end{abstract}

Keywords: Massase, Pain

\begin{abstract}
Abstrak: Pengaruh Massase Terhadap Pengurangan Rasa Nyeri pada Ibu Inpartu Kala I di BPS Nurhasanah, Kecamatan Teluk Betung Bandar Lampung. Nyeri selama persalinan umumnya terasa hebat, dan hanya $2-4 \%$ ibu saja yang mengalami nyeri ringan selama persalinan. Dalam penatalaksanaan persalinan, nyeri dapat dikurangi dengan teknik farmakologi dan non farmakologi. Salah satu teknik non farmakologi adalah massase. Berdasarkan hasil prasurvey peneliti, penatalaksanaan nyeri yang dilakukan oleh ibu inpartu selama ini di BPS adalah melakukan teknik relaksasi, distraksi dengan berjalan, aktivitas secara perlahan, dan pemilihan posisi persalinan yang nyaman bagi ibu. Penelitian ini bertujuan untuk mengetahui pengaruh massase terhadap pengurangan rasa nyeri pada ibu inpartu kala I di BPS Nurhasanah Tahun 2016. Penelitian ini menggunakan Rancangan penelitian pra eksperimen dengan pendekatan One Group Pretest-Postest. Teknik sampling adalah accidental sampling. Populasi dalam penelitian ini adalah jumlah ibu bersalin selama 1 bulan terakhir yaitu di bulan Mei 2016 sejumlah 34 ibu. Peneliti mengambil sampel seluruh ibu inpartu kala I BPS Nurhasanah selama penelitian berlangsung di Bulan Juni 2016 sejumlah $20 \mathrm{ibu}$. Dimana pengumpulan data menggunakan lembar observasi dengan alat ukur skala nyeri Wong Baker Pain Rating Scale yaitu skala nyeri berdasarkan ekspresi wajah dengan rentang skor 0 sampai 5. kemudian dianalisa secara univariat dan disajikan dalam bentuk tabel distribusi tingkat nyeri sebelum dan sesudah dilakukan massase. Kemudian dilakukan analisa bivariat menggunakan uji-T. Dari hasil penelitian yang dilakukan bahwa rata-rata nyeri persalinan sebelum dilakukan teknik massase adalah 3,450 dengan standar deviasi 0,944. Rata-rata nyeri persalinan setelah diberikan teknik massase adalah 2,400 dengan standar deviasi 0,994.Ada pengaruh Pengaruh Massase Terhadap Pengurangan Rasa Nyeri pada Ibu Inpartu Kala I di BPS Nurhasanah, Kecamatan Teluk Betung Bandar Lampung Tahun 2016 ( $p$ value $0,000<0,05)$.
\end{abstract}

Kata kunci: Massase, Rasa nyeri 
Persalinan merupakan saat yang menegangkan dan menggugah emosi ibu dan keluarganya bahkan dapat pula menjadi saat yang menyakitkan dan menakutkan bagi ibu. Nyeri selama persalinan umumnya terasa hebat, dan hanya $2-4 \%$ ibu saja yang mengalami nyeri ringan selama persalinan. Nyeri dan ketakutan menimbulkan stress (Bobak, 2005).

Rasa nyeri yang dirasakan tergantung pada banyak faktor psikososial, derajat kualitas nyeri yang dirasa ditentukan oleh pengalaman sebelumnya dan seberapa baik pengalaman tersebut diingat. Persepsi nyeri juga tergantung pada pemahaman tentang penyebab rasa nyeri dan kemampuan untuk memikul konsekuensinya (Indrayani \& Djami, 2013).

Berbagai upaya dilakukan untuk menurunkan nyeri pada persalinan, baik secara farmakologi maupun nonfarmakologi. Manajemen nyeri secara farmakologi lebih efektif dibanding dengan metode nonfarmakologi, namun metode farmakologi lebih mahal, dan berpotensi mempunyai efek yang kurang baik. Sedangkan metode nonfarmakologi lebih murah, simple, efektif dan tanpa efek yang merugikan (Sulistyawati, 2012).

Menghilangkan rasa nyeri ialah hal yang penting. Bukan jumlah nyeri yang dialami wanita yang perlu dipertimbangkan, akan tetapi harapan tetang cara mengatasi nyeri tersebut dapat terpenuhi. Hal ini mempengaruhi persepsinya tentang pengalaman melahirkan sebagai pengalaman buruk atau baik. Untuk mengatasi hal tersebut bidan dapat mengajarkan metode non farmakologi untuk meredakan rasa nyeri (Bobak, 2005).

Salah satu metode yang sangat efektif dalam menanggulanginya adalah dengan massage yang merupakan salah satu metode nonfarmakologi yang dilakukan untuk mengurangi nyeri persalinan. Bidan mempunyai andil yang sangat besar dalam mengurangi nyeri nonfarmakologi (Maryunani, 2010).

Studi yang dilakukan oleh National Birthday Trust terhadap 1000 wanita menunjukkan bahwa $90 \%$ wanita merasakan manfaat relaksasi dan pijatan untuk meredakan nyeri. Nyeri persalinan merupakan masalah yang sangat mencemaskan bagi ibu inpartu, khususnya ibu primigravida, dan biasanya yang paling sering dilakukan untuk mengurangi rasa nyeri adalah dengan metode massage, baik oleh petugas kesehatan, keluarga pasien maupun pasien itu sendiri (Nurasiah, 2012).

Massase adalah melakukan tekanan tangan pada jaringan lunak, biasanya otot atau ligamentum, tanpa menyebabkan gerakan atau perubahan posisi sendi untuk meredakan nyeri, menghasilkan relaksasi, dan atau memperbaiki sirkulasi (Maryunani, 2010). Tindakan massase ini akan menutup pintu gerbang jalur nyeri. Dengan massase juga akan menimbulkan efek psikososial yang baik untuk ibu bersalin. Di anjurkan agar massase selama persalinan harus bersifat terus menerus. Hal tersebut harus dilakukan karena terdapat kecenderungan rasa nyeri akan meningkat jika pemijatan di hentikan, hal ini disebabkan sistem saraf yang sudah terbiasa terhadap stimulus tersebut dan organ indera terbiasa merespon nyeri tersebut.

Salah satu metode massase adalah rubbing. Cara massase ini bisa dilakukan dengan bantuan penolong persalinan atau keluarga yang mendampingi dengan cara pemijatan dengan gerakan melingkar pada punggung sekitar torakal 10, 11, 12, lumbal 1 dan sakral 2, 3, 4 selama kontraksi uterus dan ulangi kembali bila ada kontraksi (Tamsuri A, 2007)

Berdasarkan hasil presurvey yang peneliti lakukan di BPS Nurhasanah pada tanggal 9 Februari 2016, didapatkan data jumlah persalinan selama tahun 2015 sebanyak 163 persalinan. Penatalaksanaan nyeri yang dilakukan oleh ibu inpartu selama ini adalah melakukan teknik relaksasi, distraksi dengan berjalan, aktivitas secara perlahan, dan pemilihan posisi persalinan yang nyaman bagi ibu. Selama ini di BPS belum pernah dilakukan metode nonfarmakologi seperti massase terhadap ibu inpartu untuk mengurangi rasa nyeri persalinan.Untuk itu peneliti tertarik untuk meneliti apakah ada pengaruh massase terhadap pengurangan rasa nyeri pada persalinan, sehingga peneliti mengambil judul "Pengaruh Massase Terhadap Pengurangan Rasa Nyeri pada Ibu Inpartu Kala I, di BPS Nurhasanah pada Tahun 2016".

\section{METODE PENELITIAN}

Penelitian ini rancangan analisis dengan menggunakan pra eksperimen dengan pendekatan One Group Pretest-Postest (Arikunto, 2013). Rancangan ini tidak ada kelompok pembanding (control), tetapi paling tidak sudah dilakukan observasi pertama (pre test) yang memungkinkan peneliti dapat menguji perubahan-perubahan yang terjadi setelah adanya eksperimen (program), karena peneliti mencoba mengkaji adanya pengaruh massage terhadap rasa nyeri pada ibu inpartu kala I.

Teknik sampling yang digunakan dalam 
penelitian ini adalah accidental sampling. Populasi dalam penelitian ini adalah jumlah ibu bersalin selama 1 bulan terakhir yaitu di bulan Mei 2016 sejumlah 34 ibu. Peneliti mengambil sampel seluruh ibu inpartu kala I BPS Nurhasanah selama peenlitian berlangsung di Bulan Juni 2016 sejumlah 20 ibu. Dimana pengumpulan data menggunakan lembar observasi dengan alat ukur skala nyeri Wong Baker Pain Rating Scale yaitu skala nyeri berdasarkan ekspresi wajah dengan rentang skor 0 sampai 5. kemudian dianalisa secara univariat dan disajikan dalam bentuk tabel distribusi tingkat nyeri sebelum dan sesudah dilakukan massase. Kemudian dilakukan analisa bivariat menggunakan uji-T.

\section{HASIL}

Tabel 1. Tingkat Nyeri Sebelum dan Sesudah Dilakukan Massase

\begin{tabular}{cccccc}
\hline Nyeri & Mean & SD & Min & Max & n \\
\hline $\begin{array}{c}\text { Sebelum } \\
\text { massase }\end{array}$ & 3,450 & 0,944 & 2 & 5 & 20 \\
\hline $\begin{array}{c}\text { Sesudah } \\
\text { massase }\end{array}$ & 2,400 & 0,994 & 1 & 5 & 20 \\
\hline
\end{tabular}

Berdasarkan hasil analisa univariat pada tabel 1 diatas diketahui sebelum pemberian teknik massase, diperoleh rata-rata nyeri persalinan terhadap 20 ibu sebelum pemberian terapi adalah 3,45 dengan standar deviasi 0,944. Skor nyeri minimal 2 dan maksimal 5. Dan sesudah pemberian massase diperoleh rata-rata nyeri persalinan setelah pemberian terapi adalah 2,4 dengan standar deviasi 0,994. Skor nyeri minimal 1 dan maksimal 5.

Tabel 2. Pengaruh Massase Terhadap Rasa Nyeri Pada Ibu Inpartu

\begin{tabular}{lccccc}
\hline $\begin{array}{l}\text { Nyeri } \\
\text { persalinan }\end{array}$ & Mean & SD & t-test & $\begin{array}{c}\boldsymbol{p} \text { - } \\
\text { value }\end{array}$ & $\mathbf{n}$ \\
\cline { 1 - 1 } $\begin{array}{l}\text { Sebelum } \\
\text { massase }\end{array}$ & 3,450 & 0,944 & 6,185 & 0,000 & 20 \\
\cline { 1 - 1 } $\begin{array}{l}\text { Setelah } \\
\text { massase }\end{array}$ & 2,400 & 0,994 & 0,222 & & \\
\hline
\end{tabular}

Berdasarkan hasil analisis uji bivariat pada tabel 2 diatas, hasil uji statistik didapatkan $p$ value $=0,000$ ( $p$-value $<\alpha=0,05)$ yang berarti ada pengaruh Pengaruh Massase Terhadap Pengurangan Rasa Nyeri pada Ibu Inpartu Kala I di BPS Nurhasanah tahun 2016.

\section{PEMBAHASAN}

Rata-rata nyeri sebelum dilakukan adalah terapi 3,450 dan standar deviasi 0,944. Setelah dilakukan terapi didapat rata-rata nyeri 2,400 dengan standar deviasi 0,994. Terlihat nilai mean perbedaan antara sebelum dan sesudah terapi adalah 1,050 dengan standar deviasi 0,579 . Hasil uji statistik didapatkan nilai $p$ value $=0,000$ yang berarti $p<\alpha=0,05$ (Ho ditolak dan Ha diterima), maka dapat disimpulkan bahwa ada pengaruh Pengaruh Massase Terhadap Pengurangan Rasa Nyeri pada Ibu Inpartu Kala I di BPS Nurhasanah, Str.Keb tahun 2016.

Menurut Bobak (2005) Rasa nyeri muncul akibat respons psikis dan reflek fisik. Rasa nyeri dalam persalinan menimbulkan gejala yang dapat dikenali. Peningkatan sisitem saraf simpatik timbul sbagai respon terhadap nyeri dan dapat mengakibatkan perubahan tekanan darah, denyut nadi, pernafasan dan warna kulit. Serangan mual, muntah dan keringat berlebihan juga sangat sering terjadi. Selama persalinan kala satu, nyeri terutama dialami karena rangsangan nosiseptor dalam adneksa, uterus, dan ligamen pelvis.

Banyak penelitian yang mendukung bahwa nyeri persalinan kala adalah akibat dilatasi serviks dan segmen uterus bawah, dengan distensi lanjut, peregangan, dan trauma pada serat otot dan ligamen yang menyokong struktur ini. Peregangan otot polos telah ditunjukkan menjadi rangsang pada nyeri viseral. Intensitas nyeri yang dialami pada kontraksi dikaitkan dengan derajat dan kecepatan dilatasi serviks dan segmen uterus bawah. Intensitas dan waktu nyeri dikaitkan dengan terbentuknya tekanan intrauterin yang menambah dilatasi struktur tersebut. Pada awal persalinan, terdapat pembentukan tekanan perlahan, dan nyeri dirasakan kira-kira 20 detik setelah mulainya kontraksi uterus. Pada persalinan selanjutnya, terdapat pembentukan tekanan lebih cepat yang mengakibatkan waktu kelambatan minimal sebelum adanya persepsi nyeri. Ketika serviks dilatasi cepat pada wanita yang tidak melahirkan, mereka mengalami nyeri serupa dengan yang dirasakan selama kontraksi uterus (Nolan, 2010).

Sejalan dengan Hasil penelitian Rini Hariani Ratih (2010) tentang Pengaruh Metode Massage Terhadap Pengurangan Intensitas Nyeri pada Persaliinan Kala I di Klinik Bersalin Fatimah Ali I Marindal Medan Tahun 2010 menggunakan desain quasi-eksperimen yang bersifat one group pretest-posttest. Jumlah sampel dalam penelitian ini adalah 20 orang dan dibagi menjadi dua kelompok intervensi yaitu metode massage effleurage 10 orang, metode 
massage abdominal lifting 10 orang. Analisa data yang digunakan adalah uji $t$-dependen dan $t$ independent. Dari hasil uji t-dependen diperoleh intensitas nyeri sebelum dilakukan metode massage effleurage rata-ratanya adalah 6,10 setelah dilakukan metode massage effleurage diperoleh rata-ratanya adalah 3,90. Sedangkan intensitas nyeri sebelum dilakukan metode massage abdominal lifting rata-ratanya adalah 5,50 setelah dilakukan metode massage abdominal lifting diperoleh rata-ratanya 370 . Nilai rata-rata perbedaan kelompok metode massage effleurage adalah 2,200 sedangkan nilai rata-rata perbedaan kelompok metode massage abdominal lifting adalah 1,800. Maka dapat disimpulkan ada perbedaan yang signifikan antara intensitas nyeri sebelum dilakukan dan setelah dilakukan intervensi. Dari hasil penelitian ini diketahui metode massage efektif dalam mengurangi intensitas nyeri pada persalinan kala I (nilai $p=0,174$ ). Dari hasil penelitian ini dinyatakan bahwa metode massage dapat digunakan sebagai intervensi dalam asuhan kebidanan kepada ibu bersalin.

$$
\text { Rangsangan persalinan kala I }
$$

ditransmisikan dari serat eferen melalui pleksus hipogastrik superior, inferior, dan tengah, rantai simpatik torakal bawah, dan lumbal,keganglia akar saraf posterior pada T10 sampai L1. Nyeri dapat disebarkan dari area pelvis ke umbilikus, paha atas, dan area midsakral. Pada penurunan janin, biasanya pada kala II, rangsangan ditransmisikan melalui saraf pudendal melalui pleksus sakral ke ganglia akar saraf posterior pada S2 sampai S4 (Maryunani, 2010).

Massase Rubbing punggung merupakan metode menurunkan nyeri dengan teknik massase dan penggosokan (rubbing) pada daerah punggung yaitu pada thoracic, 10, 11, 12 dan lumbal 1. Impuls nyeri selama persalinan kala I di transmisikan oleh segmen saraf spinal (thoracic 11 dan thoracic 12) dan asesoris thoracic bawah simpatis lumbalis. Nervus ini berasal dari uterus dan serviks (Bobak, 2005).

Ketidaknyamanan dari perubahan serviks dan iskemia uterus adalah nyeri visceral yang berlokasi di abdomen bawah menyebar ke daerah lumbal belakang dan paha bagian dalam. Dalam penatalaksanaan persalinan, nyeri dapat dikurangi dengan teknik farmakologi dan non farmakologi. Salah satu teknik non farmakologi adalah massase, salah satu teknik massase yaitu massase rubbing. Massase Rubbing punggung dengan tangan merupakan teknik penurunan nyeri dengan gosokan lembut pada saat terjadi nyeri. Untuk nyeri persalinan pada columna vertebra thoracic 10, 11, 12. Manfaat massase rubbing punggung selain untuk melancarkan peredaran darah juga diduga dapat menurunkan nyeri melalui mekanisme gate control termasuk pada nyeri persalinan tanpa mempengaruhi kontraksi uterus. Massase punggung klien dapat menurunkan tegangan dan meningkatkan relaksasi, dengan menggunakan penekanan dan menurunkan nyeri. Contoh dari tipe massase adalah massase tangan dan kaki, back rubs, massase sakral dan otot punggung (Harry, 2010)

Rubbing adalah pemijatan atau usapan lembut pada bagian bawah punggung dengan rubbing dapat meningkatkan relaksasi juga menurunkan nyeri uterus berkontraksi dengan menutup pintu gerbang teori gate control. Rubbing juga meningkatkan endorphin yang berfungsi neurotransmiter dan neuromodulator untuk menghambat atau menurunkan sensasi nyeri. Cara rubbing bisa dilakukan dengan bantuan penolong persalinan atau keluarga yang mendampingi dengan cara pemijatan dengan gerakan melingkar pada punggung sekitar torakal 10, 11, 12, lumbal 1 dan sakral 2, 3, 4 selama kontraksi uterus dan ulangi kembali bila ada kontraksi (Maryunani, 2010).

Menurut peneliti dari hasil data didapatkan perbedaan skala nyeri setiap responden berbedabeda, hal ini disebabkan karena setiap responden memiliki intensitas nyeri yang berbeda-beda. Selain itu banyak faktor yang berperan dalam mengurangi rasa nyeri saat persalinan, seperti pada hasil penelitian terlihat dari ibu yang mendapat teknik massase yang sesuai merasakan nyeri persalinan yang ringan, hal ini dikarenakan pada saat dilakukan massase selain mengurangi ketegangan pada otot juga mengurangi rasa takut atau kecemasan yang ada pada diri pasien dan juga ketika dilakukan massase, ibu merasakan sentuhan sehingga ibu merasa nyaman.

Pada ibu yang dilakukan massase namun tetap mengalami nyeri berat bisa dikarenakan faktor pengalaman buruk persalinan yang lalu juga akan menambah kecemasan dan kepribadian ibu berperan penting terhadap rasa sakit, ibu yang secara alamiah tegang dan cemas akan lebih lama dalam menghadapi stres dibandingkan dengan wanita yang rileks dan percaya diri.

\section{SIMPULAN}

1. Rata-rata nyeri pada ibu bersalin sebelum diberikan teknik massase adalah 3,450 dengan standar deviasi 0,944 .

2. Rata-rata nyeri pada ibu bersalin setelah diberikan teknik massase adalah 2,400 dengan standar deviasi 0,994 
3. Ada pengaruh Pengaruh Massase Terhadap Pengurangan Rasa Nyeri pada Ibu Inpartu Kala I di BPS Nurhasanah tahun 2016 ( $p$-value $0,000<0,05)$.

\section{SARAN}

1. Bagi penolong persalinan, dapat menerapkan prosedur massase rubbing dalam mengurangi rasa nyeri persalinan dengan memberikan penjelasan mengenai prosedur massase rubbing dan meminta persetujuan pasien terlebih dahulu.

2. Perlunya dilakukan sosialisasi pada ibu bersalin mengenai massase rubbing ini semenjak ibu melakukan pemeriksaan kehamilan

3. Bagi peneliti lebih lanjut dengan menambah variable lain yang bisa diteliti ataupun membandingkan dengan teknik massase lainnya seperti effleurage dan counterpressure yang berhubungan dengan pengurangan rasa nyeri.

\section{DAFTAR PUSTAKA}

Arikunto. 2013. Prosedur Penelitian Suatu Pendekatan Praktik. Jakarta: Rineka Cipta.

Bobak, Lowdermilk. 2005. Keperawatan Maternitas. Jakarta: Penerbit Buku Kedokteran EGC.

Harry. 2010. Buku Kebidanan: Patologi dan Fisiologi Kebidanan. Yogyakarta: Andi off set.

Indrayani, Djami. 2013. Asuhan Persalinan dan Bayi Baru Lahir. Jakarta: Trans InfoMedia.

Maryunani, Anik. 2010. Nyeri dalam Persalinan Teknik dan Cara Penangananya. Jakarta: Trans Info Media.

Nolan, Mary. 2010. Kelas Bersalin. Yogyakarta: Golden Books.

Nurasiah, Ai. 2012. Asuhan Persalinan Bagi Bagi Bidan. Bandung: Refika Aditama.

Ratih, Rini Hariani. 2010. Pengaruh Metode Massage Terhadap Pengurangan Intensitas Nyeri pada Persalinan Kala I di Klinik Bersalin Fatimah Ali I Marindal Medan Tahun 2010. https://www.researchgate.net/researcher/49 571191_Rini_Hariani_Ratih (Diakses pada 4 Februari 2016).

Siti, Saleha. 2009. Asuhan Kebidanan Persalinan. Jakarta: Salemba Medika.

Sulistyawati, Nugraheny. 2012. Asuhan Kebidanan Pada Ibu Bersalin. Jakarta: Salemba Medika.

Tamsuri, S.2007. Konsep dan Penatalaksanaan Nyeri. Jakarta: EGC. 